\title{
Evaluation of the milk urea content in relation to milk production and composition in dairy cows
}

\author{
Petra Timkovičová Lacková, Iveta Maskal’ová, Vladimír Vajda \\ University of Veterinary medicine and Pharmacy in Košice, Department of Nutrition, \\ Dietetics and Animal Breeding, Košice, Slovak Republic
}

Received January 3, 2019

Accepted June 13, 2019

\begin{abstract}
The aim of this study was to evaluate the milk urea content along with the dynamics of lactation and milk components in production dependency in Holstein dairy cows. Evaluation of daily milk yield in relation to milk urea presented a positive regression dependency, which was the strongest in early lactation $(\mathrm{r}=0.860 ; P<0.001)$, decreasing in mid lactation $(\mathrm{r}=0.329 ; P<0.001)$ and late lactation $(\mathrm{r}=0.261 ; P<0.001)$. Evaluation of milk protein in relation to milk urea showed a negative regression dependency, which was the strongest in early lactation $(\mathrm{r}=-0.850 ; P<0.001)$, decreasing in mid lactation $(\mathrm{r}=-0.819 ; P<0.001)$ and late lactation $(\mathrm{r}=-0.679 ; P<0.001)$. The somatic cell counts in relation to milk urea confirmed a negative regression dependency in early lactation $(\mathrm{r}=-0.635 ; P<0.05)$ and mid lactation $(\mathrm{r}=-0.818 ; P<0.05)$, but no significance was found in late lactation. The results of the study confirm the influence of production factors (milk quantity and milk components) on the milk urea content. Dependencies found between the production, milk components and milk urea are applicable for the evaluation of protein nutrition and metabolic transformation of nutrients in dairy cows.
\end{abstract}

Milk yield, milk components, lactation stage

Urea is synthesized in the liver of ruminants as a final product of protein metabolism by the detoxification of circulating ammonia in the bloodstream. The source of endogenous urea is ammonia, which originates from rumen degradation of feed protein and unused passes through the rumen wall from where it is transmitted through the portal vein to the liver. Another source of endogenous urea is ammonia formed by the deamination of amino acids absorbed in the small intestine which are not involved in protein synthesis due to the imbalance of essential amino acids and ammonia from proteolysis of peripheral tissues in early lactation during negative energy balance. Endogenous urea passes from the liver to the bloodstream where a large portion is excreted through urine into the environment, representing a direct nitrogen loss. Part of the blood urea is returned into the rumen by saliva and blood through the rumen wall which stabilizes ammonia levels for the synthesis of microbial protein, and a portion of the urea passes into the milk (Powell et al. 2014). According to Bogucki et al. (2005) the optimal concentration of milk urea (MU) for dairy cows should range from 15 to $30 \mathrm{mg} / \mathrm{dl}$. However, Pytlewski et al. (2010) reported an optimal MU value of up to $25 \mathrm{mg} / \mathrm{dl}$. Reduced amount of MU indicates a deficit of protein in feed, when it occurs there is a lack of ammonia available to ruminal microorganisms. An elevated level of MU is characteristic of excess protein or a deficit of energy in the feed ration (Weeks and Hristov 2017). The evaluation of $\mathrm{MU}$ is an important tool for assessing the protein-energy ratio of nutrients in the feed ration for dairy cows. In addition to nutritional factors that have the biggest effect on the concentration of MU, it may be influenced by non-nutritional factors such as breed, parity, season and production factors such as milk yield and milk components (Čobanović et al. 2017). 
The aim of this study was to evaluate the MU content along with the dynamics of lactation and milk components in production dependency in Holstein dairy cows over a one year period.

\section{Materials and Methods}

Data collection and management of dairy herd

The study was performed on a dairy farm with a total number of 600 Holstein dairy cows during the year 2017 (from January to December). An average milk production was $10154 \mathrm{~kg}$ of milk per standard 305-day lactation. Production above 305 days of lactation was not evaluated in the study. Dairy cows were fed and selected in groups according to the milk yield and days in milk (DIM) as follows: 0-120 DIM (early lactation), 121-210 DIM (mid lactation), 211-305 DIM (late lactation). Furthermore, according to MU concentration they were divided into the following three categories: MU up to $25 \mathrm{mg} / \mathrm{dl}, \mathrm{MU} 25-30 \mathrm{mg} / \mathrm{dl}$, MU above $30 \mathrm{mg} / \mathrm{dl}$, with the optimal level of MU being considered up to $30 \mathrm{mg} / \mathrm{dl}$. Milk urea content was evaluated along with the dynamics of lactation and milk components in production dependency.

Dairy cows were kept in a free-stall system and fed a total mixed ration (TMR) consisting of maize silage, clover silage, grass silage, alfalfa silage, rye silage, grass hay, alfalfa hay, wheat straw, cereal grain mixture, rapeseed meal, wet distillers' grains and a concentrate mixture. The TMR were formed monthly depending on the nutrient requirements according to the milk yield and the capacity of dry matter intake for all groups of dairy cows according to the stage of lactation. The TMR was offered twice a day using a mixer wagon and it was gathered up several times per day to ensure ad libitum feed intake with a regular control of the feed remains in the feed bunk. Samples of TMR were analysed by conventional methods (Commission Regulation EC No. 152/2009 of 27.1.2009) to examine nutrients such as a dry matter (DM), crude protein (CP), fat, neutral detergent fibre (NDF), acid detergent fibre (ADF), starch and ash, monthly over the year. Non-fibre carbohydrates (NFC) and net energy of lactation (NEL) were calculated by the equations based on the analysed nutrients content of the feeds (NRC 2001). The composition and analysed nutrients content of TMR according to the stage of lactation are summarized in Table 1.

The analysed average nutritional composition of TMR for the year with a balanced CP (157.58, 154.17, $157.00 \mathrm{~g} / \mathrm{kg} \mathrm{DM}$, respectively) confirmed a decrease of NEL (6.61,6.37, 6.07 MJ/kg DM, respectively) in the feeding groups along with an increased DIM and a decreased milk yield. In the feed rations for early, mid and late lactation, the change in NEL was caused by a decrease in the starch content $(251.92,232.58,162.25 \mathrm{~g} / \mathrm{kg} \mathrm{DM}$, respectively) and an increase in NDF (341.92, 377.50, $417.83 \mathrm{~g} / \mathrm{kg} \mathrm{DM}$, respectively).

The cows were milked twice a day and individual milk samples were analysed once per month to evaluate the milk yield, milk components, and MU in the Central Milk Laboratory (accredited in accordance with the international standard ISO/IEC 17025:2005) in collaboration with The Breeding Services of Slovakia, s.e. (state-owned enterprise) using the breeding information system. Milk protein, fat, lactose and MU were determined by the Fourier transformed infrared analyser method MilkoScan FT+ (Foss Electric, Hillerød, Denmark) and Bentley FTS (Bentley Instruments Inc., Chaska, USA), the somatic cell counts (SCC) were analysed using a Fossomatic FC (Foss Electric, Hillerød, Denmark) and Bentley FCM (Bentley Instruments Inc., Chaska, USA). Daily yields of protein, fat and lactose were calculated by multiplying the percentage of milk components with milk yield per day.

\section{Statistical analysis}

The obtained data were processed by the IBM SPSS Statistics version 24.0 (IBM Corporation, Armonk, USA). Results were expressed as the mean and standard deviation. One-way Analysis of Variance (ANOVA) and Tukey test for multiple comparison of means were conducted to evaluate the differences in milk yield, milk components and milk urea parameters, with the stage of lactation set as the main factor at a significance level of $P<0.001$. Subsequently, the analysis of correlation between MU and the daily milk yield, milk protein and SCC was performed in dairy cows during lactation. For all parameters, the effects were declared significant at $P<0.05$ and $P<0.001$.

\section{Results}

\section{Milk production and composition}

Milk production, milk components and MU during lactation are summarized in Table 2. The daily milk yield during standard lactation was on average $35.70 \pm 9.21 \mathrm{~kg} / \mathrm{d}$ with a peak in the $3^{\text {rd }}$ month of lactation $(40.78 \pm 9.22 \mathrm{~kg} / \mathrm{d})$. According to the lactation stage, a significant $(P<0.001)$ decrease in milk yield was confirmed $(39.91,36.26$, $30.41 \mathrm{~kg} / \mathrm{d}$, respectively) proportionally to the increase in DIM $(75.49,164.57,253.62$, respectively). Persistency of lactation evaluated as the decrease in milk yield from the peak 
Table 1. The composition and analysed nutrient content of the total mixed ration according to the stage of lactation.

\begin{tabular}{|c|c|c|c|c|}
\hline & & Early lactation & Mid lactation & Late lactation \\
\hline \multicolumn{5}{|c|}{ Composition of TMR } \\
\hline Maize silage & $\mathrm{kg}$ & $20.00-36.00$ & $19.00-39.00$ & $8.00-36.00$ \\
\hline Clover silage & $\mathrm{kg}$ & $6.00-16.00$ & $4.00-10.00$ & $8.00-14.00$ \\
\hline Grass silage & $\mathrm{kg}$ & $2.00-5.00$ & 4.00 & $4.00-6.00$ \\
\hline Alfalfa silage & $\mathrm{kg}$ & - & 13.00 & 22.00 \\
\hline Rye silage & $\mathrm{kg}$ & 8.00 & 12.00 & 17.00 \\
\hline Grass hay & $\mathrm{kg}$ & $0.80-1.00$ & $0.80-2.00$ & $1.00-3.00$ \\
\hline Alfalfa hay & $\mathrm{kg}$ & 1.00 & - & - \\
\hline Wheat straw & $\mathrm{kg}$ & $0.50-0.80$ & 0.50 & 1.00 \\
\hline Cereal grain mixture & $\mathrm{kg}$ & $0.50-4.50$ & $0.80-3.50$ & $1.00-1.30$ \\
\hline Rapeseed meal & $\mathrm{kg}$ & $2.00-4.00$ & $3.20-5.30$ & $2.50-6.00$ \\
\hline Wet distillers' grains & $\mathrm{kg}$ & 4.00 & 4.00 & - \\
\hline Concentrate mixture & $\mathrm{kg}$ & 4.50 & 1.50 & 0.30 \\
\hline \multicolumn{5}{|c|}{ Nutrient content of TMR $($ mean \pm SD) } \\
\hline $\mathrm{DM}$ & $\mathrm{g} / \mathrm{kg}$ & $446.75 \pm 16.82$ & $422.17 \pm 25.06$ & $410.92 \pm 32.40$ \\
\hline DMI & $\mathrm{kg} / \mathrm{d}$ & $25.03 \pm 0.74$ & $22.15 \pm 0.56$ & $20.35 \pm 0.71$ \\
\hline $\mathrm{CP}$ & $\mathrm{g} / \mathrm{kg} \mathrm{DM}$ & $157.58 \pm 2.19$ & $154.17 \pm 3.61$ & $157.00 \pm 2.92$ \\
\hline Starch & $\mathrm{g} / \mathrm{kg} \mathrm{DM}$ & $251.92 \pm 6.42$ & $232.58 \pm 16.53$ & $162.25 \pm 33.45$ \\
\hline Fat & $\mathrm{g} / \mathrm{kg} \mathrm{DM}$ & $43.33 \pm 0.78$ & $37.58 \pm 0.67$ & $35.67 \pm 0.98$ \\
\hline $\mathrm{NDF}$ & $\mathrm{g} / \mathrm{kg} \mathrm{DM}$ & $341.92 \pm 10.75$ & $377.50 \pm 7.88$ & $417.83 \pm 12.89$ \\
\hline $\mathrm{ADF}$ & $\mathrm{g} / \mathrm{kg} \mathrm{DM}$ & $211.75 \pm 5.49$ & $229.75 \pm 5.08$ & $267.33 \pm 13.82$ \\
\hline $\mathrm{NFC}$ & $\mathrm{g} / \mathrm{kg} \mathrm{DM}$ & $382.42 \pm 9.21$ & $357.00 \pm 10.45$ & $308.92 \pm 21.22$ \\
\hline NEL & $\mathrm{MJ} / \mathrm{kg} \mathrm{DM}$ & $6.61 \pm 0.08$ & $6.37 \pm 0.08$ & $6.07 \pm 0.21$ \\
\hline Ash & $\mathrm{g} / \mathrm{kg} \mathrm{DM}$ & $74.50 \pm 3.18$ & $73.83 \pm 4.97$ & $80.58 \pm 9.39$ \\
\hline
\end{tabular}

DM - dry matter, DMI - dry matter intake, CP - crude protein, NDF - neutral detergent fibre, ADF - acid detergent fibre, NFC - non-fibre carbohydrates, NEL - net energy of lactation, d - day, TMR - total mixed ration, SD - standard deviation

Table 2. Milk production and milk components (mean \pm SD) during lactation.

\begin{tabular}{lcccc}
\hline Variable & Standard lactation & Early lactation & Mid lactation & Late lactation \\
\hline DIM & $305.00 \pm 0.00$ & $75.49 \pm 26.07^{\mathrm{c}}$ & $164.57 \pm 25.85^{\mathrm{b}}$ & $253.62 \pm 25.69^{\mathrm{a}}$ \\
Milk yield kg/d & $35.70 \pm 9.21$ & $39.91 \pm 9.17^{\mathrm{a}}$ & $36.26 \pm 8.12^{\mathrm{b}}$ & $30.41 \pm 7.63^{\mathrm{c}}$ \\
MU mg/dl & $27.84 \pm 7.15$ & $27.15 \pm 6.99^{\mathrm{c}}$ & $28.14 \pm 7.06^{\mathrm{b}}$ & $28.65 \pm 7.05^{\mathrm{a}}$ \\
Protein \% & $3.22 \pm 0.34$ & $3.04 \pm 0.29^{\mathrm{c}}$ & $3.23 \pm 0.31^{\mathrm{b}}$ & $3.39 \pm 0.32^{\mathrm{a}}$ \\
Protein yield kg/d & $1.14 \pm 0.22$ & $1.20 \pm 0.26^{\mathrm{a}}$ & $1.15 \pm 0.25^{\mathrm{b}}$ & $1.02 \pm 0.24^{\mathrm{c}}$ \\
Fat \% & $3.65 \pm 0.77$ & $3.44 \pm 0.79^{\mathrm{c}}$ & $3.59 \pm 0.69^{\mathrm{b}}$ & $3.88 \pm 0.71^{\mathrm{a}}$ \\
Fat yield kg/d & $1.27 \pm 0.33$ & $1.35 \pm 0.37^{\mathrm{a}}$ & $1.27 \pm 0.29^{\mathrm{b}}$ & $1.16 \pm 0.28^{\mathrm{c}}$ \\
Lactose \% & $4.87 \pm 0.21$ & $4.94 \pm 0.20^{\mathrm{a}}$ & $4.88 \pm 0.20^{\mathrm{b}}$ & $4.79 \pm 0.21^{\mathrm{c}}$ \\
Lactose yield kg/d & $1.74 \pm 0.47$ & $1.97 \pm 0.46^{\mathrm{a}}$ & $1.77 \pm 0.42^{\mathrm{b}}$ & $1.46 \pm 0.39^{\mathrm{c}}$ \\
SCC 10 $/ \mathrm{ml}$ & $433.20 \pm 1253.80$ & $373.75 \pm 1184.83^{\mathrm{c}}$ & $430.57 \pm 1220.96^{\mathrm{b}}$ & $497.85 \pm 1347.37^{\mathrm{a}}$ \\
\hline
\end{tabular}

DIM - days in milk, MU - milk urea, SCC - somatic cell counts, d - day, SD - standard deviation Different superscripts in the same row are significantly different at $P<0.001$

reached $5.2 \%$ for standard lactation. The lowest decrease of milk yield was at $3.2 \%$ in early lactation, $4.2 \%$ for mid lactation, and averaged $7.0 \%$ in late lactation.

The contents of milk protein and fat for standard lactation were $3.22 \pm 0.34$ and $3.65 \pm 0.77 \%$, respectively. A significant $(P<0.001)$ increase of milk protein content 
$(3.04 \pm 0.29,3.23 \pm 0.31,3.39 \pm 0.32 \%)$ and milk fat content $(3.44 \pm 0.79,3.59 \pm 0.69$, $3.88 \pm 0.71 \%$ ) was confirmed in continuous lactation.

Daily milk protein yield for standard lactation was confirmed at an average of $1.14 \pm 0.22 \mathrm{~kg} / \mathrm{d}$. In early lactation the daily milk protein yield was $1.20 \pm 0.26 \mathrm{~kg} / \mathrm{d}$ and with continuous lactation this significantly $(P<0.001)$ decreased with a mean value of $1.15 \pm 0.25 \mathrm{~kg} / \mathrm{d}$ in mid lactation and $1.02 \pm 0.24 \mathrm{~kg} / \mathrm{d}$ in late lactation. Daily milk fat yield for standard lactation was $1.27 \pm 0.33 \mathrm{~kg} / \mathrm{d}$. A significant $(P<0.001)$ decrease of milk fat yield $(1.35,1.27,1.16 \mathrm{~kg} / \mathrm{d}$, respectively) was confirmed in continuous lactation.

The milk lactose content for standard lactation was $4.87 \pm 0.21 \%$. The highest milk lactose was found in early lactation $(4.94 \pm 0.20 \%)$ with a significant $(P<0.001)$ decrease in mid $(4.88 \pm 0.20 \%)$ and late $(4.79 \pm 0.21 \%)$ lactation. The daily milk lactose yield for standard lactation was $1.74 \pm 0.47 \mathrm{~kg} / \mathrm{d}$. A significant $(P<0.001)$ decrease in the milk lactose yield $(1.97,1.77,1.46 \mathrm{~kg} / \mathrm{d}$, respectively) was confirmed in continuous lactation.

Evaluation of the milk yield in relation to $\mathrm{MU}$

The mean value of MU for standard lactation was $27.84 \pm 7.15 \mathrm{mg} / \mathrm{dl}$. In continuous lactation, a significant $(P<0.001)$ increase of MU was confirmed (Table 2$)$. The dynamics of the daily milk yield in relation to MU according to the stage of lactation are summarized in Fig. 1.

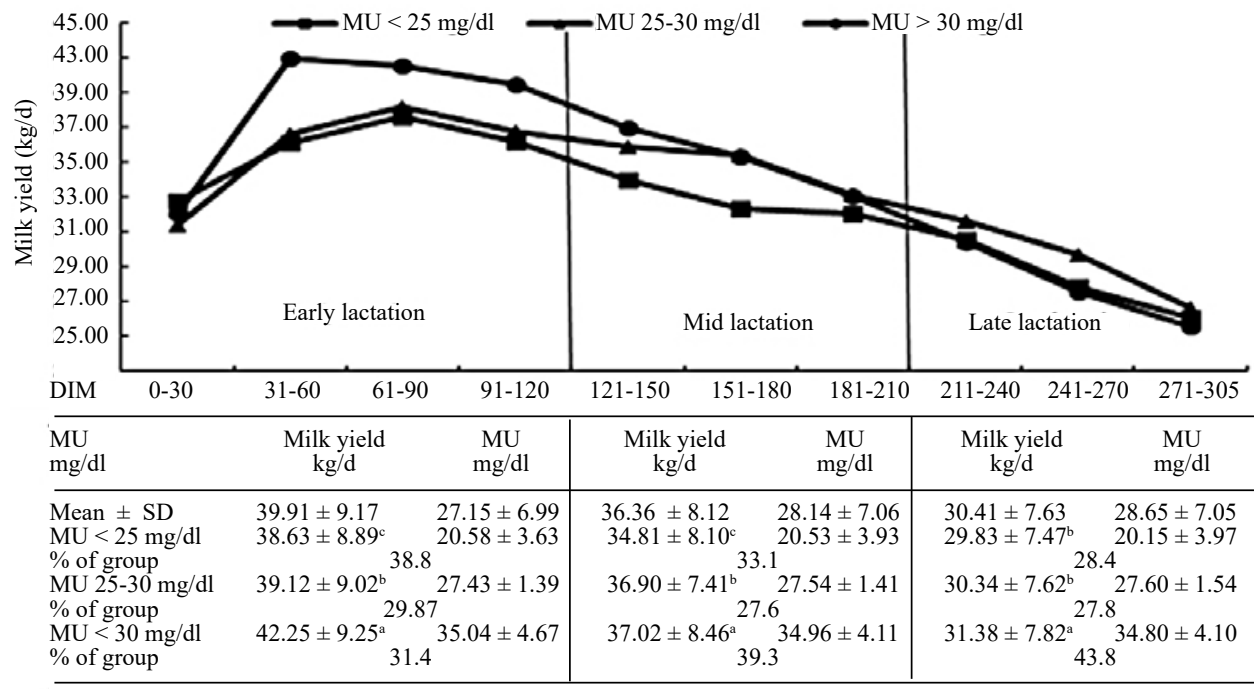

Fig. 1. The dynamics of daily milk yield in relation to MU

MU - milk urea, DIM - days in milk, d - day, SD - standard deviation

Different superscripts in the same column are significantly different at $P<0.001$

In early lactation the mean value of the milk yield was $39.91 \pm 9.17 \mathrm{~kg} / \mathrm{d}$ with an average MU of $27.15 \pm 6.99 \mathrm{mg} / \mathrm{dl}$. When dividing the dairy cows according to MU levels, the highest milk yield was $42.25 \pm 9.25 \mathrm{~kg} / \mathrm{d}$, which was found in cows with over the limit MU levels (above $30 \mathrm{mg} / \mathrm{dl}$ ) at an average of $35.04 \pm 4.67 \mathrm{mg} / \mathrm{dl}$, which was determined individually in $31.4 \%$ of dairy cows. A gradually significant $(P<0.001)$ decrease in the milk yield showed a positive regression dependency to $\mathrm{MU}(\mathrm{r}=0.860)$.

In mid lactation the mean milk yield was $36.26 \pm 8.12 \mathrm{~kg} / \mathrm{d}$ and the analysed MU level was $28.14 \pm 7.06 \mathrm{mg} / \mathrm{dl}$. The highest mean milk yield was $37.02 \pm 8.46 \mathrm{~kg} / \mathrm{d}$ which was 
confirmed in the group with a mean over-the-limit MU level of $34.96 \pm 4.11 \mathrm{mg} / \mathrm{dl}$, which was determined individually in $39.3 \%$ of dairy cows. The significant $(P<0.001)$ decrease in milk yield positively correlated with the decrease in MU $(r=0.329)$.

In late lactation the average milk yield was $30.41 \pm 7.63 \mathrm{~kg} / \mathrm{d}$ and the analysed MU level was $28.65 \pm 7.05 \mathrm{mg} / \mathrm{dl}$. The highest milk yield with a mean value of $31.38 \pm 7.82 \mathrm{~kg} / \mathrm{d}$ was recorded in the group with a mean over-the-limit MU level of $34.80 \pm 4.10 \mathrm{mg} / \mathrm{dl}$ which was determined individually in $43.8 \%$ of dairy cows. The significant $(P<0.001)$ decrease of milk yield positively correlated with a decrease in MU $(\mathrm{r}=0.261)$.

In a yearly evaluation the over-the-limit MU level (above $30 \mathrm{mg} / \mathrm{dl}$ ) with a mean value $34.94 \pm 4.28 \mathrm{mg} / \mathrm{dl}$ for standard lactation was confirmed in $37.6 \%$ of dairy cows in the herd, and these cows reached the highest milk yield for standard lactation with an average of $11226 \mathrm{~kg}$. Dairy cows with MU levels in the range of $25-30 \mathrm{mg} / \mathrm{dl}$ with a mean value of $27.52 \pm 1.42 \mathrm{mg} / \mathrm{dl}$ made up $28.1 \%$ of the herd with a confirmed milk yield of $10746 \mathrm{~kg}$ on average for standard lactation. Dairy cows with a MU of up to $25 \mathrm{mg} / \mathrm{dl}$ and a mean value of $20.32 \pm 3.92 \mathrm{mg} / \mathrm{dl}$ accounted for $34.3 \%$ of the herd with an average milk yield of $8053 \mathrm{~kg}$ for standard lactation. Persistency of lactation at different MU levels showed that the group of dairy cows with MU levels above $30 \mathrm{mg} / \mathrm{dl}$ and with the highest milk yield achieved a peak in the milk yield between 31-60 DIM and a persistency of lactation of $5.4 \%$. In the groups of dairy cows with MU levels between $25-30 \mathrm{mg} / \mathrm{dl}$ and under $25 \mathrm{mg} / \mathrm{dl}$, respectively, a later peak of milk yield was confirmed (61-90 DIM) but persistency of lactation was found to be lower (4.7, 4.8\%, respectively) than in the group with MU levels above $30 \mathrm{mg} / \mathrm{dl}$.

Evaluation of milk protein in relation to $\mathrm{MU}$

An evaluation of milk protein in relation to MU according to the stage of lactation is summarized in Fig. 2. The milk protein content in relation to the MU level confirmed a negative regression dependency where an increase in the protein content during the lactation stages was associated with lower MU levels.

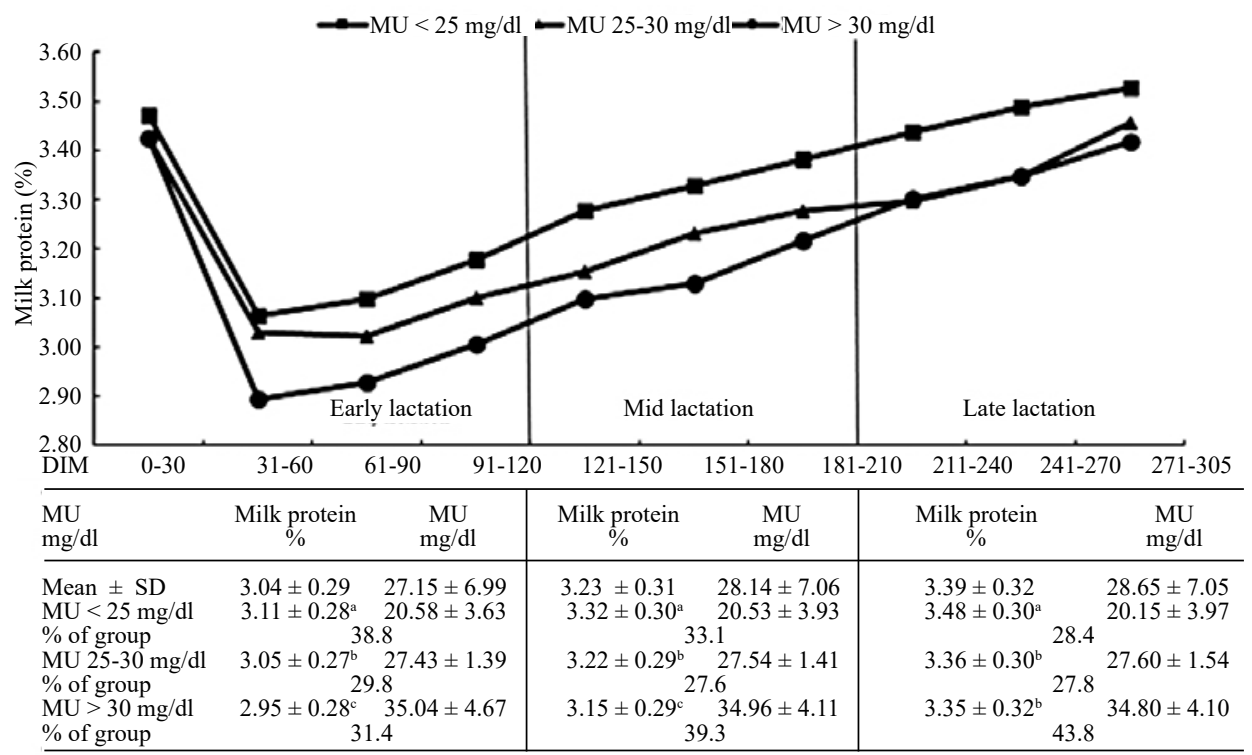

Fig. 2. Evaluation of milk protein in relation to $\mathrm{MU}$

MU - milk urea, DIM - days in milk, d - day, SD - standard deviation

Different superscripts in the same column are significantly different at $P<0.001$ 
In early lactation the mean value of milk protein was $3.04 \pm 0.29 \%$ with MU level of $27.15 \pm 6.99 \mathrm{mg} / \mathrm{dl}$. The lowest milk protein content with a mean value of $2.95 \pm 0.28 \%$ was recorded in the group with a mean over-the-limit MU (above $30 \mathrm{mg} / \mathrm{dl}$ ) of $35.04 \pm 4.67 \mathrm{mg} / \mathrm{dl}$ which was found in $31.4 \%$ of dairy cows. A gradually significant $(P<0.001)$ increase in the milk protein content showed a negative regression relationship to $\mathrm{MU}(\mathrm{r}=-0.850)$.

In mid lactation the average value of milk protein was $3.23 \pm 0.31 \%$ with an average MU level of $28.14 \pm 7.06 \mathrm{mg} / \mathrm{dl}$. The lowest level of milk protein $(3.15 \pm 0.29 \%)$ was found in the group of dairy cows with a mean over-the-limit MU of $34.96 \pm 4.11 \mathrm{mg} / \mathrm{dl}$ which was individually determined in $39.3 \%$ of dairy cows. A gradually significantly $(P<0.001)$ increasing level of milk protein showed a negative regression dependency to MU ( $\mathrm{r}=-0.819)$.

In late lactation the mean milk protein content was $3.39 \pm 0.32 \%$ and the MU level was $28.65 \pm 7.05 \mathrm{mg} / \mathrm{dl}$. The lowest mean milk protein content was $3.35 \pm 0.32 \%$ which was found in the group of dairy cows with an over-the-limit MU level of $34.80 \pm 4.10 \mathrm{mg} / \mathrm{dl}$ determined individually in $43.8 \%$ of dairy cows with a gradually significant $(P<0.001)$ increase of milk protein which showed a negative regression dependency in relation to $\mathrm{MU}$ $(\mathrm{r}=-0.679)$.

\section{Evaluation of SCC in relation to MU}

The SCC of milk in relation to MU levels displayed a negative regression dependency, where decreasing SCCs were found in the individual phases of lactation associated with increasing MU levels. The SCC for standard lactation was $433.20 \times 10^{3} / \mathrm{ml}$. A significant $(P<0.001)$ increase in SCC from $373.75 \times 10^{3} / \mathrm{ml}$ in early lactation to $430.57 \times 10^{3} / \mathrm{ml}$ in mid lactation and $497.85 \times 10^{3} / \mathrm{ml}$ in late lactation was found with continuous lactation (Table 2).

Evaluation of SCC in relation to MU according to the stage of lactation is summarized in Fig. 3.

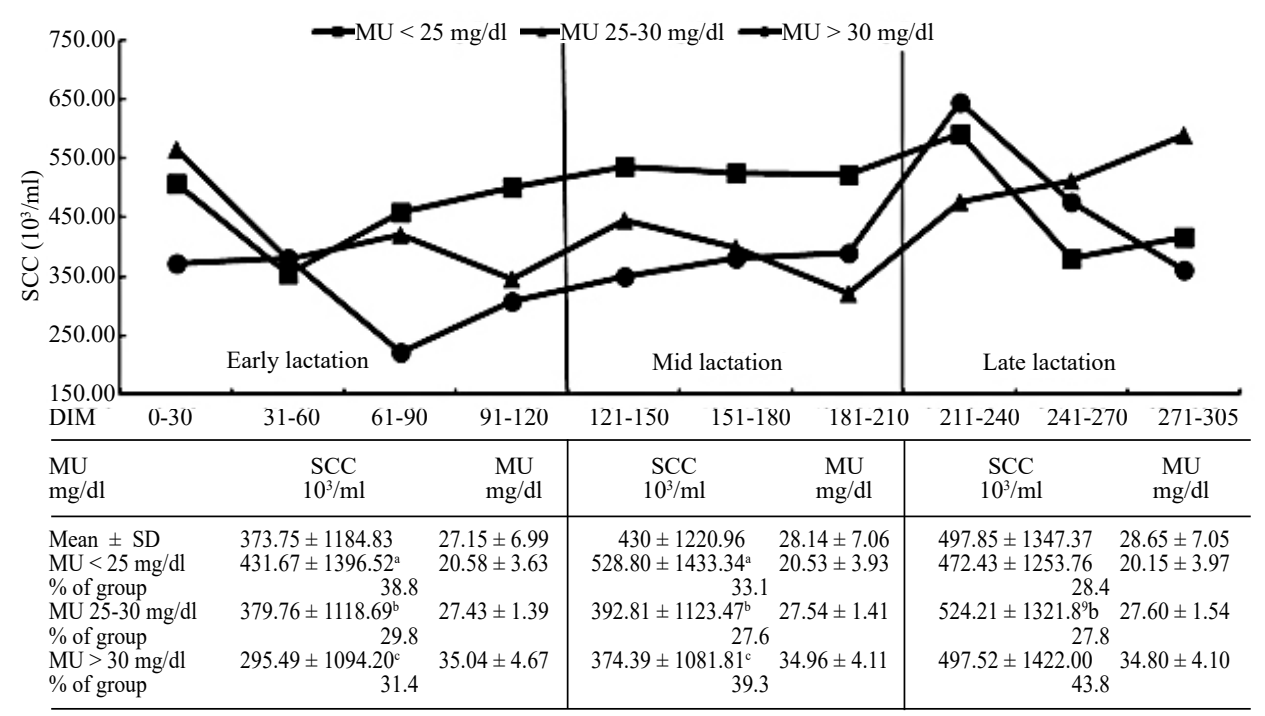

Fig. 3. Evaluation of SCC in relation to MU

MU - milk urea, DIM - days in milk, d - day, SD - standard deviation, SCC - somatic cell counts

Different superscripts in the same column are significantly different at $P<0.05$ 
The cows in early and mid lactation had the lowest SCC with the mean values of $295.49 \times 10^{3} / \mathrm{ml}$ and $374.39 \times 10^{3} / \mathrm{ml}$, respectively, in groups with over-the-limit MU levels (above $30 \mathrm{mg} / \mathrm{dl}$ ) of on average $35.04 \pm 4.67 \mathrm{mg} / \mathrm{dl}$ and $34.96 \pm 4.11 \mathrm{mg} / \mathrm{dl}$, respectively, these were individually determined in $31.4 \%$ and $39.3 \%$ of dairy cows. The SCC of milk significantly $(P<0.05)$ decreased in negative regression dependency to MU levels in early $(\mathrm{r}=-0.635)$ and mid $(\mathrm{r}=-0.818)$ lactation. In late lactation the SCC in relation to MU did not show any significant dependency.

\section{Discussion}

The declining dynamics of milk yield found in the course of lactation is consistent with conclusions by Vijayakumar et al. (2017) influenced by homeorhetic stimulation of metabolic regulation of nutrient intake for milk synthesis as well as the synthetic capacity of the mammary gland by different recovery of the secretory cells at the peak and end of lactation.

The synthetic capacity of milk components was evaluated on yearly average by analysing the content and daily yield of milk protein and fat in relation to the nutrient intake according to the stage of lactation in dairy cows. The confirmed increase in the milk protein content during lactation is consistent with a previous study by Bondan et al. (2018). The decrease in the milk yield in continuous lactation causes the protein content to remain more concentrated (Idamokoro et al. 2017). The increase in milk fat found over the course of lactation is conditioned by the changing milk yield during lactation but also by the changing carbohydrate composition in TMR. The shift of the ratio NDF to NFC in TMR from 1:1.1 in early lactation to 1:0.95 in mid lactation and 1:0.74 in late lactation affects the fermentation in rumen and the ratio of acetic acid to propionic acid as main precursors for milk fat synthesis (Shuiep et al. 2016).

An evaluation of daily protein and fat yield in milk showed their decrease with continuous lactation. Our results correspond with the conclusions by Silvestre et al. (2009) who explained the decrease of milk protein and fat yields over the course of lactation as an effect of the decrease of milk yield in continuous lactation.

The evaluated relationships of content and yield of milk fat and protein by homeorhetic regulation have an effect on the genetic potential of a herd, which influences the milk quantity and synthesis of milk components by means of hormonal regulation of nutrient intake in preference to the mammary gland (Vijayakumar et al. 2017). In contrast, the nutritional effects of aminogenic, lipogenic and glucogenic intake significantly influence the proportion of milk components and serve as a marker for evaluating of nutrition (Ty a si et al. 2015). In the early lactation group the analysed nutrient composition and the determined DMI of TMR converted to an actual milk yield of $40 \mathrm{~kg} / \mathrm{d}$ supplied production at a mean 49 percentile. The high number of animals $(n=150)$ and the production imbalance mean that the average production in the fourth quartile of the animals $(51.60 \pm 3.77 \mathrm{~kg})$ exceeds the calculated NEL requirement by $37 \mathrm{MJ}$ and $\mathrm{CP}$ by $1000 \mathrm{~g}$ per day according to standard requirements (NRC 2001), whereupon animals react by increasing the mobilisation of body reserves during the period of negative energy balance. This balance explains a decrease in the mean content of milk protein $(3.04 \pm 0.29 \%)$ and milk fat $(3.44 \pm 0.79 \%)$, which were mainly found in the dairy cows with a production over the group average. In the mid lactation group the nutrient intake converted to actual milk yield $(36.26 \pm 8.12 \mathrm{~kg} / \mathrm{d})$ showed a balanced nutrient and energy intake to supply the standard requirements for the milk yield. In the late lactation group the nutrient intake converted to actual milk yield $(30.41 \pm 7.63 \mathrm{~kg} / \mathrm{d})$ showed a balanced nutrient and energy intake to supply the standard requirements for the milk yield. 
The confirmed decrease in the milk lactose content and yield during lactation is consistent with a previous study by Henao-Velásquez et al. (2014), who explained this relationship as a decrease in the milk yield in continuous lactation, when the synthesis of lactose in the mammary gland regulates milk secretion.

An evaluation of the daily milk yield in relation to the MU level confirmed a positive regression dependency, which was the strongest in the early lactation group $(\mathrm{r}=0.860$; $P<0.001)$, decreasing with continuous lactation, in mid lactation $(\mathrm{r}=0.329 ; P<0.001)$ and in late lactation $(\mathrm{r}=0.261 ; P<0.001)$. Our conclusions are in agreement with $\mathrm{Siachos}$ et al. (2017), who confirmed a positive relationship between the milk yield and MU. Other studies confirmed this relationship as a negative dependency (Abdouli et al. 2008). The highest milk yield along with over-the-limit level of MU was confirmed in the early lactation group of dairy cows, which indicated the metabolic support of milk synthesis by mobilizing body reserves where deamination of amino acids leads to increased energy and nitrogen availability for the synthesis of milk and urea (Wattiaux et al. 2005).

The evaluation of milk protein in relation to MU confirmed a negative regression dependency, which was the strongest in early lactation $(\mathrm{r}=-0.850 ; P<0.001)$, decreasing in mid lactation $(\mathrm{r}=-0.819 ; P<0.001)$ and late lactation $(\mathrm{r}=-0.679 ; P<0.001)$. Our results are consistent with previous studies by Zhang et al. (2018), who confirmed the negative dependency between milk protein and MU in dairy cows. Other studies examining this relationship did not find a significant correlation between these parameters (Kananub et al. 2018). The lowest protein content in milk along with the over-the-limit MU level confirmed in a group of dairy cows in early lactation indicates a limited intake of amino acids from TMR. Amino acids released from muscle by proteolysis have a different composition compared to milk protein and they are used for urea synthesis after deamination (Nousiainen et al. 2004).

Somatic cell counts in relation to MU confirmed a negative regression dependency in early $(\mathrm{r}=-0.635 ; P<0.05)$ and mid lactation $(\mathrm{r}=-0.818 ; P<0.05)$ but no significance was found in late lactation. These results are in agreement with previous reports by Kananub et al. (2018) who confirmed the negative dependency between SCC and levels of MU, whereby this relationship explained as unclear forasmuch as those variables refer to physiological processes which are not clearly connected. Milk urea is related to the evaluation of protein nutrition in dairy cows and SCC reflects the degree of irritation in the mammary gland. On the other hand, Silva et al. (2016) confirmed the positive relationship between SCC and MU levels, which is caused by the irritating action of urea molecules on the cell walls of milk alveoli in the mammary gland.

The higher MU may indicate parity effects, whereby the dairy herd in our study mainly consisted of dairy cows in the first and second lactation. According to Jílek et al. (2006) higher MU concentrations were determined in cows in their first and second lactations, in contrast to groups in their third and fourth lactations.

In conclusion, our results confirmed the significant impact of production factors (milk quantity and milk components) on the MU content. A positive correlation between production and MU with the most pronounced effect in early lactation $(r=0.860)$ was confirmed. The milk protein in relation to MU levels showed a negative regression dependency, which was the strongest $(r=-0.850)$ in early lactation. The SCC in relation to MU confirmed a negative regression dependency in early $(r=-0.635)$ and mid $(r=-0.818)$ lactation. It was concluded that MU concentration should be evaluated in association with DIM, parity, milk yield, milk protein content and SCC. These variables should be considered as potential sources of misinterpretation in exploring the relationship between MU and nutritional management. Confirmed dependencies between production, milk components and MU are applicable for the evaluation of protein nutrition and metabolic transformation of nutrients in dairy cows. They are a useful tool for identifying and diagnosing problems with remedial and nutritional management on dairy farms. 


\section{Acknowledgement}

The study was supported by the grant VEGA 1/0785/16.

\section{References}

Abdouli H, Rekik B, Haddad-Boubaker A 2008: Non-nutritional factors associated with milk urea concentrations under Mediterranean conditions. World J Agric Sci 4: 183-188

Bogucki M, Neja W, Oler A, Krężel S 2005: Poziom mocznika w mleku krow w zależności od wybranych czynnikow [Urea level in cow's milk depending on selected factors]. Rocz AR Pozn CCCLXXVI Zootech 56: $57-61$

Bondan C, Folchini JA, Noro M, Quadros DL, Machado KM, González FHD 2018: Milk composition of Holstein cows: a retrospective study. Cienc Rural 48: 1-8

Čobanović K, Kučević D, Plavšić M, Bogdanović V 2017: Impact of non-nutritional factors on milk urea concentration and its relationship with production and fertility traits in Vojvodina dairy herds. Mljekarstvo 67: $267-276$

Henao-Velásquez AF, Múnera-Bedoya OD, Herrera AC, Agudelo-Trujillo JH, Cerón-Muñoz MF 2014: Lactose and milk urea nitrogen: fluctuations during lactation in Holstein cows. R Bras Zootec 43: 479-484

IBM Corporation 2016: IBM SPSS Statistics for Windows, Version 24.0. Armonk, NY: IBM Corporation

Idamokoro EM, Muchenje V, Masika PJ 2017: Yield and milk composition at different stages of lactation from a small herd of Nguni, Boer, and non-descript goats raised in an extensive production system. Sustainability 9: 1000

Jílek F, Řehák D, Volek J, Štípková M, Němcová E, Fiedlerová M, Rajmon R, Švestková D 2006: Effect of herd, parity, stage of lactation and milk yield on urea concentration in milk. Czech J Anim Sci 51: 510-517

Kananub S, Jawjaroensri W, VanLeeuwen J, Stryhn H, Arunvipas P 2018: Exploring factors associated with bulk tank milk urea nitrogen in Central Thailand. Vet World 11: 642-648

National Research Council (NRC) 2001: Nutrient requirements of dairy cattle, $7^{\text {th }}$ Revised Edition. The National Academies Press, Washington, D.C., 381 p.

Nousiainen J, Shingfield KJ, Huhtanen P 2004: Evaluation of milk urea nitrogen as a diagnostic of protein feeding. J Dairy Sci 87: 386-398

Powell JM, Rotz CA, Wattiaux, MA 2014: Potential use of milk urea nitrogen to abate atmospheric nitrogen emissions from Wisconsin dairy farms. J Environ Qual 43: 1169-1175

Pytlewski J, Antkowiak I, Skrzypek R 2010: Relationships between somatic cells counts and urea level in the milk of Polish Holstein-Friesian cows of black-and-white and red-white varieties. Acta Sci Pol Zootechnica 9: 39-50

Shuiep ES, Eltaher HA, El Zubeir IEM 2016: Effect of stage of lactation and order of parity on milk composition and daily milk yield among local and crossbred cows in South Darfur State, Sudan. Sch J Agric Vet Sci 17: 86-99

Siachos N, Panousis N, Arsenos G, Valergakis GE 2017: Investigation of milk urea nitrogen concentration and factors affecting its variation in Greek Holstein herds. J Hell Vet Med Soc 68: 423-432

Silva VN, Rangel AHN, Galvão Júnior JGB, Urbano SA, Borba LH, Novaes LP, Lima Júnior DM 2016: Influence of somatic cell count in the composition of Girolando cow's milk in tropical zone. Trop Subtrop Agroecosyst 19: $101-107$

Silvestre AM, Martins AM, Santos VA, Ginja MM, Colaço JA 2009: Lactation curves for milk, fat and protein in dairy cows: A full approach. Livest Sci 122: 308-313

Tyasi TL, Gxasheka M, Tlabela CHP 2015: Assessing the effect of nutrition on milk composition of dairy cows: A review. Int J Curr Sci 17: 56-63

Vijayakumar M, Park JH, Ki KS, Lim DH, Kim SB, Park SM, Jeong HY, Park BY, Kim TI 2017: The effect of lactation number, stage, length, and milking frequency on milk yield in Korean Holstein dairy cows using automatic milking system. Asian-Australas J Anim Sci 30: 1093-1098

Wattiaux MA, Nordheim EV, Crump P 2005: Statistical evaluation of factors and interactions affecting dairy herd improvement milk urea nitrogen in commercial Midwest dairy herds. J Dairy Sci 88: 3020-3035

Weeks HL, Hristov AN 2017: Short communication: Analytical method and amount of preservative added to milk samples may alter milk urea nitrogen measurements. J Dairy Sci 100: 1502-1506

Zhang H, Wang M, Jiang H, Cui Y, Xia H, Ni W, Li M, Karrow NA, Yang Z, Mao Y 2018: Factors affecting the milk urea nitrogen concentration in Chinese Holstein cows. Anim Biol 68: 193-211 